УДК 342.951

DOI https://doi.org/10.32844/2618-1258.2019.3-1.24

ЗАЯЦь Б.Р.

\title{
ІСТОРІОГРАФІЯ РОЗВИТКУ ІНСТИТУТУ \\ ПРАВОВОГО РЕГУЛЮВАННЯ ЗАЛУЧЕННЯ ГРОМАДСЬКОСТІ \\ ДО ЗАХОДІВ ІЗ ЗАПОБІГАННЯ КОРУПЦІЇ В ОРГАНАХ ДЕРЖАВНОЇ ВЛАДИ ТА ОРГАНАХ МІСЦЕВОГО САМОВРЯДУВАННЯ
}

У статті висвітлено сутність та зміст фундаментальних концепцій розкриття формо-змістовних характеристик корупції в Україні. Зазначено, що історія державотворення засвідчує, що будь-яка держава, незалежно від особливостей організації іiї інститутів на певному етапі власного розвитку неодмінно постає перед проблемою нівеляції внутрішньої компоненти публічно-правового суверенітету внаслідок згаданої вище транссуб'єктивізації (неправомірної зміну аутентичного суб'єкта) управлінських повноважень. Визначальним фактором названого процесу і виступає корупція.

Зазначено, що кращого розв'язання проблеми слід чітко розуміти, що корупція перш за все $є$ соціальним явищем і має свою давню історію, яка прямо пов'язана із появою у житті людей владних та грошових взаємовідносин. 3'ясовано, що від античної доби та аж до сьогодення існує конфліктна ситуація навколо питань, що стосуються здатності відповідальних органів у країнах контролювати осіб, а також групи осіб, що вважають, що їхні власні інтереси стоять вище держави та загального добробуту суспільства в цілому.

Наведено, що об’єктивні причини розвитку корупції вказують на те, що вона призводить до реальної загрози розвитку суспільства, а темпи ії зростання несуть явні виклики національній безпеці нашої країни. Зазначено, що пріоритетом для будь-якої держави є дотримання прав і свобод людини і громадянина; закон один для всіх і кожен громадянин своєї країни має чітко його дотримуватись, бо збереження існуючого корупційного середовища в Україні неодмінно призведе до знищення іiі державності, адже Україна за всю свою історію вже зазнавала важких випробувань: від втрати своєї незалежності й до боротьби за неї протягом багатьох століть.

3'ясовано, що визначальність міжгалузевого підходу у контексті будь-яких подальших спеціалізованих наукових розвідок явища корупції зумовлено можливістю більш детального відображення ідентифікуючих особливостей кожної з вузькогалузевих (у нашому випадку адміністративно-правової) методик розкриття суті цього явища через виокремлення синалагматичних (міжгалузевих) зв'язків останнього, а відтак і розробити практично-ціннісну та логічно-структуровану модель запобігання та протидії вказаному дефекту функціонування управлінського механізму.

Ключові слова: корупиія, прояви, запобігання, протидія, адміністративноправовий аспект, профілактика.

The article contain the essence of fundamental concepts of disclosure of form-content characteristics of corruption in Ukraine. It is stated that the history of state formation shows that any state, regardless of the peculiarities of the organization of its institutions, at a certain stage of its own development, inevitably faces the problem of obstruction of the internal component of public-legal sovereignty as a result of the transubjectivization (unauthorized change of administrative identity) of public procedures. Corruption is a decisive factor in this process.

It is noted that for the better solution of the problem it should be clearly understood that corruption is first of all a social phenomenon that has a long history, which is directly connected with the public order formation. It has been found that from the ancient times

(C) ЗАЯЦЬ Б.Р. - аспірант кафедри адміністративного права та адміністративного процесу (Львівський державний університет внутрішніх справ) 
up to the present day there has been a conflict over issues concerning the ability of responsible authorities in different countries to control individuals, as well as groups of individuals who believe that their own interests stand above the state and the general welfare of society as a whole.

It is stated that objective reasons for the development of corruption indicate that it manifest a real threat to the development of society, and that its growth rate presents clear challenges to the national security of our country. It is noted that the respect for human and citizen's rights and freedoms is the main priority for any state. The law is one for all, and every citizen of his or her country must adhere strictly to it, because preserving the current corruption environment in Ukraine will inevitably lead to the destruction of the state order, because throughout its history, Ukraine has already undergone different difficulties: from the loss of its independence to the struggle for it throughout for many centuries.

It is revealed that the main productive potential of the cross-sectoral approach in the context of any further specialized scientific investigations of the phenomenon of corruption is conditioned by the possibility of a more detailed reflection of the identifying features of each of the narrow (in our case administrative-legal) methods of disclosing the essence of this phenomenon through representation of the integrative affects of corruption as the social phenomenon, and therefore to develop a practical and logicallystructured model of counteraction to the named defect in management mechanism.

Key words: corruption, manifestations, prevention, counteraction, administrativelegal aspect, prophylaxis.

Вступ. Корупція, підвалини якої було закладено ще в давнину, нині $є$ одним із найпоширеніших асоціальних явищ у всьому світі. Слід зазначити, що корупція є характерним феноменом для усіх держав у всьому світі. Ані демократичний, ані тоталітарні режими не змогли подолати цей негативний феномен. Загальновідомим є той факт, що корупція спричиняє максимальне нівелювання ефективності низки урядових програм та заходів, повного економічного занепаду та різкого зниження життя громадян, невиправданого різкого його розшарування за отриманими доходами та умовами життя. Все це спонукає міжнародну спільноту та його громадські організації шукати правові механізми та способи вирішення цієї складної комплексної проблеми. Розроблення та реалізація стратегії запобігання негативному феномену корупції повинна грунтуватися на науковому баченні сутності корупції власне як соціального феномену, позаяк без розуміння іiі соціальної сутності не можливо окреслити реальні цілі запобігання та протидії.

Окреслюючи сутність корупції, слід враховувати три основних моменти, а саме: по-перше - корупція є соціальний феномен, а не конкретне суспільно небезпечне діяння; по-друге, в правовому вимірі корупція - це комплексне поняття, котре охоплює систему взаємопов'язаних деліктів, як кримінально-правових, адміністративно-правових, дисциплінарних так і цивільноправових; по-третє, законодавче тлумачення корупції не дає правоохоронним органам жодних додаткових правових засобів щодо підстав юридичної відповідальності за корупційні діяння, як не дає таких засобів правоохоронним органам і визначення поняття злочинність.

Проблемі дослідження ретроспективи інтеграції соціальних інститутів в парадигму протидії корупційним феноменам приділена увага в низці наукових досліджень вітчизняних та зарубіжних науковців, серед яких доцільно виділити: В. Авер'янова, О. Андрійко, Л. Аркуші, Л. Багрій-Шахматова, О. Бандурки, Д. Бахраха, Ю. Битяка, Р. Калюжного, С. Ківалова, 3. Кісіль, Р.-В. В. Кісіль, В. Коваленка, Р. Клітгарда, Л. Коваля, І. Коліушка, В. Колпакова, А. Комзюка, М. Костеннікова, О. Копиленка, А. Куракіна, С. Коткіна, Р. Клітгарда, В. Кудрявцева, С. Курінного, Д. Лук'янця, О. Мартиненка, Н. Матюхіної, В. Мілера, С. Невмержицького, О. Негодченка, Н. Нижник, С. Роуз-Екерман, С. Стеценка, А. Шайо, С. Шалгунової, Ю. Шемшученка, В. Шкарупи. Незважаючи на велику кількість наукових розвідок наукової спільноти з цього питання, досі відсутнє єдине консолідоване визначення корупції як соціального явища, передумов ії̈ виникнення, єдиної концепції протидії цьому негативному феномену.

Постановка завдання. Мета цієї публікації - проаналізувати витоки та ключові запоруки розвитку інституту правового регулювання залучення громадськості до заходів із запобігання корупції в органах державної влади та органах місцевого самоврядування

Результати дослідження. Історія корупції є історією людської цивілізації, позаяк корупція як соціальний феномен у своїх проявах не має жодних ані часових, ані географічних меж, 
оскільки повсякчас має місце там, де є держава. Свідченням цього є історичні джерела різноманітних епох та народів. Слушною $є$ думка професора М. Мельника «...історико-правові дослідження достовірно засвідчують той факт, що корупція існувала у суспільстві завжди з моменту виникнення держави, а отже і утворення державного апарату управління суспільством [1, с. 9].

3 метою системного висвітлення описаного питання, узагальнюючи концептуальні аспекти операціоналізації історичних аспектів процесу участі соціальних інститутів у протидії корупції у світовій правовій доктрині, доцільно виділити наступні періоди розвитку соціальної інтеракції в площину резистенції корупційним проявам:

А) Античний період (від VIII ст. до н. е до VI ст. н. е.).

Цьому періоду притаманна істотна стратифікованість та сегрегація соціуму, що зумовлювало повну концентрацію соціальних свобод, а відтак і соціальних ініціатив, в межах вузького континууму привілейованих осіб. Ця модель соціальної організації, привілейовані члени соціуму водночас були домінуючими учасниками публічно-правових процесів, в межах котрих і локалізувались прояви корупції. Водночас, як зазначає Грей Джон Генрі: «Навіть найнезначніші спроби населення вплинути на безмежне свавілля чиновників зіштовхувались з рішучою та безжальною реакцією держави. ... відтак замість покращення соціального стану та підвищення соціальних стандартів через зменшення обсягу зловживань та розкрадань, ініціатори суспільного опору ставали жертвами державних репресій» [2, с. 48-49].

Позиціонований досвід резистенції соціальним антикорупційним ініціативам був притаманний і правовій моделі Стародавної Індії. Так, Г. Бонгард-Левін зазначає, що: «... ведична модель класової організації суспільства в Стародавній Індії стала основою для розквіту корупції як системного явища. Оскільки лише заможні сім'ї могли дозволити собі оплатити освіту своїх дітей, відтак лише з числа заможних громадян і формувався кістяк державних органів. Кругова порука, а подекуди і повний імунітет місцевих керівників створював запоруку повної соціальної терпимості до проявів корупції. Процес відсторонення суспільних мас від протидії посадовим зловживанням посилювався також відсутністю засобів для дієвого інформування центральної влади про дійсний стан соціальних процесів в окремих провінціях, що породжувало зневіру та фатумно-філософський погляд громадян на проблему корупції в цілому» [3, с. 72].

Резюмуючи стан ефективності участі соціальних інститутів у процесі запобігання корупції в межах Античного періоду державотворення, автор доходить висновку про наявність прямої залежності інтенсивності соціальної антикорупційної інтеракції від рівня забезпечення принаймні базових демократичних засад державного управління. Авторитарний та тоталітарні режими, властиві описаному періоду державотворення, сформували тенденцію при якій опір корупційним проявам оцінювався власне як боротьба з державним устроєм, а сам ініціатор антикорупційних заходів водночас ставав ціллю державних репресій, що формувало феномен терпимості корупції з боку соціальних інститутів.

Б) Період Середньовіччя та «Нового часу» (до середини 19 століття).

Аналіз періоду Середньовіччя та «Нового часу», на думку автора, зумовлюється однотипністю концепції ініціації соціальних процесів у більшості держав з дотриманням домінуючої ролі релігійної компоненти у процесі формування релігійного світогляду.

Ю. Жданов зазначає, що: «...середньовічні форми корупції, як предмет спеціального дослідження не викликають істотного інтересу, натомість механізми соціальної резистенції іії проявам досі належним чином не оцінені сучасною правовою доктриною, хоча і містять істотні засади для удосконалення існуючої антикорупційної системи.... Бездіяльність державних службовців, які не були зацікавлені у викритті зловживань, з огляду на кругову поруку, з часом продукував новий механізм соціального реагування на корупційні прояви - церковні сановники, користуючись можливістю безпосередньої взаємодії з вищими посадовими особами територіальних одиниць, виступали в якості «голосу народу», що дозволяло оминути бюрократичні перепони та структурувати інформацію про корупційну активність для подальшого іï дослідження» [4, с. 15-16].

Аналіз наукових розвідок, які присвячені дослідженню вказаного періоду, дають підстави стверджувати про появу перших механізмів соціального реагування на корупційні прояви із застосуванням альтернативного алгоритму виявлення, документування та припинення корупційних детермінант.

Г) Сучасний період.

Нині значну увагу в частині дослідження власне ролі соціальних інститутів в парадигмі запобігання проявам корупції ученими приділяється саме сучасному періоду. Так, для ідентифікації хронологічних меж досліджуваного періоду розвитку інституту участі громадянського 
суспільства у превенції корупційних проявів слугуватимуть власне події 1918 року. Як слушно зазначає О. Кузнецова: «... до подій жовтневої революції 1918 року, процес кооперації громадянського суспільства та правоохоронної системи царської Росії зводився виключно до повідомлень про окремі епізоди протиправної поведінки у формі заяв чи скарг. Реформація державного режиму обумовила повну реструктуризацію не лише державної вертикалі, але й соціальної архітектури. Чітке розмежування суспільства на класи, диктат пролетаріату та класова боротьба диктувала нову візію і правоохоронної/судової діяльності. Показовою є теза В.І. Леніна (Ульянова) про те, що судам, перш за все, слід ставити підсудному запитання про його класову приналежність, а вже потім досліджувати винуватість у тому чи іншому протиправному діянні. На зламі політичних епох активізація суспільних інститутів у поточних функціях держави $є$ неминучою, відтак і проблема подолання корупції теж не стала винятком 3 даного правила...» [5, с. 42].

Автор погоджується з О. Кузнецовою щодо позиції кристалізації нової доктрини перцепції сприйняття соціумом власної участі у всіх політико-правових процесах. Зміни, що відбулися у соціальній ієрархії спричинило інтеграцію у правлячу верхівку соціального кластеру пролетаріату, що в свою чергу призвело до того, що дореволюційна правляча верхівка трансформувалася у об'єкт соціальних репресій, в тому числі у контексті обвинувачення представників царського режиму варіативних форм злочинної, та корупційної діяльності, зокрема.

Так, слушною $є$ позиція В. Сухоноса [6, с. 18-19] в частині розподілу усієї моделі судочинства післяреволюційної Росії на два функціональні блоки, а саме: судовий розгляд та судову констатацію. Поділ, запропонований автором слугує акцентуванню уваги на цілковитій відмінності у зазначених підходах, котрі застосовувалися під час здійснення судочинства стосовно пролетаріату та колишньої владної еліти, позаяк власне класова ознака була домінуючим мірилом для констатації факту винуватості у вчиненні протиправного діяння незалежно від інших обставин справи.

Ключового значення для з'ясування досліджуваної проблеми, досвід післяреволюційної Росії сприяє можливості ідентифікації не лишень позитивної площини соціальної інтеграції у сферу превенції та боротьби з корупцією, але й евентуального девіантного виміру такої інтеграції, за якої соціальні інститути у певній мірі придатні спотворювати усталений алгоритм процесуальної діяльності органів публічної влади, надаючи цій діяльності забарвлення соціальної дискримінації та правового нігілізму.

Антропоморфізмом політико-правових реалій власне комуністичного періоду, безперечно слід вважати владу рад, які були наділені фактично необмеженими владними повноваженнями, особливо у період аномії центрального апарату державного управління.

Кадровий склад рад народних комісарів (рад народних уповноважених), комплектувався із населення відповідних адміністративно-територіальних одиниць, що надає можливість виснувати про можливість позиціонування цих виборних органів як інститут самоврядування населення, а відтак конструкту організаційної форми соціалістичного суспільства. Отже, діяльність рад народних комісарів (рад народних уповноважених) може бути розцінено, у взаємодії з іншими формами організації суспільства, як самостійний алгоритм об'єднання соціальних інститутів у площину корекції публічного управління у державі. На противагу усталеній у правовій концепції вузького тлумачення повноважень рад народних комісарів (рад народних уповноважених) 3 локалізації їх ролі лишень організаційними функціями $[7$, с. 82; 8, с. 251], автор схиляється до концепції, яку запропонував професор С. Шишкарьов [9, с. 47-52], відповідно до якої ради реалізовували як установчі, контрольно-наглядові, фінансові, а, у певний період й судові та правоохоронні функції.

Як зазначає С. Шишкарьов: «...відсутність реформованого судового апарату, при різкому збільшенні облікового значення загально-кримінологічної деліктності, а особливо злочинів, пов'язаних з розкраданням соціалістичного майна, підробленням офіційних документів, численними зловживаннями владними повноваженнями серед новосформованих представників нового режиму, у своєму симбіозі призводили до паралічу правоохоронної діяльності. Необхідність пошуку варіантів вирішення описаної ситуації і слугувала тим ключовим фактором, завдячуючи якому ради комісарів було наділено практично універсальними повноваженнями, включно з можливістю здійснення квазісудочинства» [9, с. 47-52].

Грунтовний аналіз детермінант інтегративного характеру владних повноважень, котрими були наділені ради народних комісарів, дає авторові підстави констатувати, що окрім детермінант, які позиціонує у своїй науковій розвідці С. Шишкарьов, основною детермінантою даного процесу було стратегічне завдання в частині децентралізації влади й автономізації окремих 
громад у процесі здійснення самоврядування універсального виду. Отже, первозданні концепції соціалізму, які, грунтуючись на цілковитому запереченні державного апарату, що властивий лише імперіалістичному ладу країн капіталізму, поширювали відмову від традиційного у сьогочасному розумінні концепту «орган державної влади». Відтак, передбачена участь інститутів суспільства у процесі реалізації усіх поточних питань, зокрема, правоохоронного та судового характеру повинна бути абсолютною, виокремлюючи лишень питання нормотворчої діяльності до виключної прерогативи центральних інститутів державної влади.

Процедурно, алгоритм здійснення судових та правоохоронних функцій радами народних комісарів (радами народних уповноважених) (далі - «муніципальне судочинство») полягав у колегіальному заслуховуванні виступу головуючого на судовому засіданні, надання пояснень особою, котра звинувачувалась у вчиненні делікту, винесення пропозицій представником трудового колективу і публічного обговорення усіх обставин справи, доконечних заходів соціального і правового впливу на деліквента. Заключним етапом муніципального судочинства було підготовка рішення ради та надсилання його за підвідомчістю.

Слід зазначити, що переважною більшістю муніципальні процеси завершувались пропозицією ради щодо пробації деліквента або порушенням клопотання до правоохоронних органів, погодженого з радою трудового колективу, щодо передачі правопорушника на поруки трудовому колективу із застосуванням заходів громадського впливу як альтернативи накладення відповідного стягнення.

У науковій розвідці А. Гайдука подано витяг з кримінологічного обліку стану реалізації кримінально-правових заходів впливу стосовно осіб, котрих звинувачено у вчиненні злочинів, пов'язаних з використанням службового становища, злочинів проти інтересів соціалістичної держави, розкрадань, службового підроблення (які становлять основну частку корупційних деліктів) за період з 1919-1923 роки за даними по Азовській, Волинській, Київській, Подільській та Полтавській губерніях. Водночас, автор зазначає, що лишень $11,4 \%$ від загальної кількості корупційних деліктів розглядались судами, інші - розглядалися муніципальними органами. Так, за результатами муніципальних проваджень за корупційні делікти піддано заходам громадського впливу - $62,3 \%$ обвинувачених, $17 \%$ деліквентів було виправдано та визнано такими, що не вчиняли інкримінованих діянь, $3 \%$ проваджень закрито з процесуальних причин (смерть обвинуваченого, зникнення особи, щодо якої було призначено муніципальний розгляд тощо), менш як $18 \%$ муніципальних слухань щодо притягнення винних за корупційні правопорушення завершувались внесенням пропозиції відповідної ради до прокуратури або слідчих департаментів в частині застосування до винних заходів юридичного примусу [10, с. 43-49].

Наведені статистичні дані засвідчують про згубну динаміку, а саме: гіпертрофовану лояльність алгоритму розгляду справ муніципальними інститутами; формальний алгоритм дослідження доказів по справі, що в свою чергу, формувало можливість безкарного вчинення суспільно-небезпечних деліктів, котрі призводили до формування соціальної терпимості до корупційних проявів у свідомості громадян. Наведені статистичні показники достеменно демонструють неготовність соціальних інститутів ранньої радянської доби навіть до частково автономного функціонування в якості самостійного суб'єкта антикорупційної діяльності.

Висновки. Узагальнення наукових розвідок про історичні витоки та детермінанти розвитку інституту правового регулювання запобігання феномену корупції у працях вітчизняних і зарубіжних учених дає авторові підстави виснувати наступне:

1) Історико-правовий вимір дослідження феноменологічного ряду явищ, які сукупно формують склад цього комплексного правового інституту, засвідчив істотну інверсифікацію підходів до нормативно-правової та науково-дослідної рефлексії його властивостей.

2) Властива Античному періоду тоталітарність державного управління, зумовлювала вкрай низький рівень продуктивності заходів громадського впливу на корупційні прояви, реалізація котрих обумовлювало скоріше застосування репресивних заходів стосовно ініціаторів антикорупційних проваджень, аніж практичні міри реагування на інформацію про відповідні делікти;

3) Поєднання державного апарату та релігійних інститутів, притаманний періоду Середньовіччя, зумовлював підвищення практичної ефективності соціального впливу на публічні процеси. Безпосередній оперативний контакт духовенства 3 населенням на місцях дозволяв консолідувати інформацію про численні зловживання представників публічного апарату, мінімізувати бюрократичні перепони щодо отримання інформації про корупційні фактори адміністративним центром, а відтак і підвищити ефективність реагування на дані факти. В межах цього періоду було практично підтверджено неефективність імперативного алгоритму залучення соціального 
середовища до протидії проявам корупції, апробацією чого слід вважати досвід державної моделі в Російській імперії кінця XVI ст.;

4) Повноцінного розвитку інститут соціального впливу на корупційні фактори набув у першій половині XX століття, що знайшло свій прояв у функціонуванні спеціальних муніципальних інститутів - рад народних комісарів та уповноважених, введенні інституту народних присяжних у функціонування судових установ, а також через істотне розширення повноважень муніципальних органів у сфері здійснення первинних правоохоронних функцій. Якісна характеристика наведеного періоду соціальної інтеракції у антикорупційну діяльність свідчить про низьку ефективність наведених процесів, що, наряду зі складною політико-правовою ситуацією, обумовлюється відсутністю чітких процесуальних регуляторів здійснення муніципальних антикорупційних проваджень, формальним підходом до вирішення справ, віднесених до відома локальних органів, низьким професійним рівнем персонального складу відповідних установ.

\section{Список використаних джерел:}

1. Мельник М.І. Корупція - корозія влади (соціальна сутність, тенденції та наслідки, заходи протидії): монографія. К. : Юридична думка, 2004. 400 с.

2. Грей Джон Генрі. Історія Стародавнього Китаю (пер.с англ.). Центрполиграф. Москва, 2006. 606с.

3. Бонгард-Левин Г.М. Древняя Индия. История и культура. Алетейя. Санкт-Петербург, 2001. 288 с.

4. Жданов Ю.А. Исторические формы коррупции. Междунар. науч.-практ. конференция «Борьба с коррупцией на Юге России как системная проблема. Препятствия и стратегии». Ростов на Дону, 2001.221 с.

5. Кузнецова О.А. Коррупционная деятельность : дис. ... канд. юрид. наук: 12.00.08. Тамбов, 2007. $208 \mathrm{c}$.

6. Сухонос В.В. Правові заходи революційного часу на теренах Росії. Суми, 2016. 187 с. $172 \mathrm{c}$.

7. Кабанов П.А. Коррупция и взяточничество в России. ИПЦ «Гузель». Нижнекамск, 1995.

8. Ключевский В.О. Русская история права. Полный курс лекций. ОЛМА-ПРЕСС Образование. Москва, 2004. 831с.

9. Шишкарев С.Н. Противодействие коррупции и практика. Монография. КДУ. Москва, 2009. 168 с.

10. Гайдук А.В. Заходи адміністративного примусу у боротьбі з корупцією в Україні: дис. ... канд. юрид. наук : 12.00.07. Київ, 2006. 193 с. 